\title{
$\begin{array}{lllllllll}\mathrm{I} & \mathrm{N} & \mathrm{S} & \mathrm{T} & \mathrm{I} & \mathrm{T} & \mathrm{U} & \mathrm{T} & \mathrm{E}\end{array}$
}

\section{Rural Children Are More Likely to Live in Cohabiting-Couple Households}

WILLIAM O'HARE, WENDY MANNING, MEREDITH PORTER, AND HEIDI LYONS

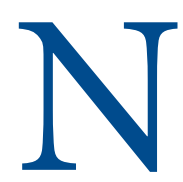
ationwide, the number of couples living together (cohabiting) has increased more than any other family form since 1995, and the number of children in cohabiting households has grown the most in rural areas. This brief focuses on the recent trends and patterns among cohabiting households with children in rural America using data from the U.S. Census Bureau. ${ }^{1}$

\section{The Share of Rural Children} Living in Cohabiting Households Has Nearly Doubled Since 2000

Although in sheer numbers many more urban children live with cohabitating parents, the rural numbers are still significant. The Census Bureau's American Community Survey (ACS) counts 4.8 million children living in cohabiting households in 2007, about 1 million of whom live in rural areas. ${ }^{2}$
Table 1 shows the various family forms in rural and urban areas. The data for 2005-2006 show rural children are more likely to be in cohabiting households than urban children (7 percent compared with 4 percent, respectively), while urban children are slightly more likely to be in single-mother families (18 percent in urban areas compared with 16 percent in rural areas). Rural and urban children are nearly as likely to live in married-couple households (66 percent in rural areas and 67 percent in urban areas), and identical shares of children live in single-father households or other family types in both areas: 3 percent were living in single-father households and 9 percent were living in other family forms. Among children living with an unmarried parent, over one-fourth of rural children are in cohabiting families compared with only 16 percent of urban children.

The difference in cohabitation rates between rural and urban children is a relatively recent phenomenon. In other words, the share of rural children living in cohabiting households has nearly doubled since $2000 .{ }^{3}$ During the same period, the share of urban children in cohabiting households rose only slightly, from 3 percent to 4 percent.

Contrary to the typical flow of social trends, which usually move from urban to rural areas, the trend toward cohabitation is more advanced in rural areas than in urban areas. We believe the high rate of rural cohabitation lies in the greater economic pressure that rural single parents feel.
Cohabiting

Married

Single-mother Single-father Other
TABLE 1. Distribution OF CHILD
AREAS: $1995-1996$ TO 2005-2006

Rural (nonmetropolitan)
Cohabiting
Married
Single-mother
Single-father
Other

\section{Urban (metropolitan)}

Source: U.S. Census Bureau Current Population Survey. 
Rural Children Living in Cohabiting Households Are More Likely to Be Poor

Children in cohabiting households differ in various ways from those in other kinds of households, but the differences in poverty rates are among the most crucial. ${ }^{4}$ We measure poverty in this brief by including income from all household members and assume that everyone in the household pools income and expenses. ${ }^{5}$ Official estimates of poverty, in contrast, do not include the cohabiting partner in determining family income and poverty.

In 2005-2006, three clear patterns in poverty emerge for children in cohabiting households (see Table 2). First, in both rural and urban areas, children in cohabiting households have poverty rates that are about twice as high as those in married-couple households. In rural areas, for example, the poverty rate for children in cohabiting-couple households is 21 percent compared with 10 percent for children in married-couple households. In urban areas, the poverty rate for children in cohabiting-couple households is 15 percent and the rate is 8 percent for children in married-couple households.

Second, in both rural and urban areas, children in cohabiting households fare better economically than children in single-mother families. In rural areas, the poverty rate for children in cohabiting-couple households is 21 percent compared with 49 percent for those in single-mother households. In urban areas, the corresponding poverty rates are 15 percent (cohabiting) and 42 percent (single-mother households).

TABle 2. PERCENT OF CHILDREN IN POVERTY BY FAMILY STRUCTURE AND METROPOLITAN STATUS: 2005-2006

$\begin{array}{ll}\text { Rural (nonmetropolitan) } & \\ \text { All children } & 18 \\ \quad \text { Cohabiting } & 21 \\ \text { Married } & 10 \\ \text { Single-mother } & 49 \\ \text { Single-father } & 21 \\ \text { Other } & 26 \\ \text { Urban (metropolitan) } & \\ \text { All children } & 16 \\ \text { Cohabiting } & 15 \\ \text { Married } & 8 \\ \text { Single-mother } & 42 \\ \text { Single-father } & 13 \\ \text { Other } & 22\end{array}$

Note: Remember, in our measure of poverty the incomes of both cohabiting partners are included.

Source: U.S. Census Bureau Current Population Survey.
Finally, among children living in cohabiting households, rural children have noticeably higher poverty rates (21 percent) than urban children (15 percent). Using a broader measure of need shows that 60 percent of rural children in cohabiting households live in low-income households (income below 200 percent of the poverty line) while only 47 percent of urban children in cohabiting households do so.

\section{Less Education and Employment May Make Rural Cohabiting Couples More Vulnerable}

The education and employment status of rural cohabiting parents puts them at a disadvantage relative to their urban counterparts. Although rural and urban couples differ little in the share without high school degrees, rural cohabiting parents, like rural individuals generally, are much less likely than their urban counterparts to have a college degree or at least some college under their belt (see Table 3). Approximately one-fourth (26 percent) of rural cohabiting men have at least some college experience, while more than one-third (34 percent) of their urban peers have been to college.The share of urban cohabiting men with a bachelor's degree or more (10 percent) is more than twice as high as their rural counterparts (4 percent). Similar differences are seen among women in cohabiting families.

TABLE 3. EdUCATION OF MALE AND FEMALE COHABITORS IN COHABITING HOUSEHOLDS WITH CHILDREN BY METROPOLITAN STATUS: 2005-2006

\section{Percent Distribution}

$\begin{array}{cccc}\begin{array}{c}\text { Less than } \\ \text { high school } \\ \text { degree }\end{array} & \begin{array}{c}\text { High school } \\ \text { degree/GED } \\ \text { only }\end{array} & \begin{array}{c}\text { Some college, } \\ \text { including } \\ \text { associate's } \\ \text { degree }\end{array} & \begin{array}{c}\text { Bachelor's } \\ \text { degree }\end{array} \\ \text { or more }\end{array}$

\begin{tabular}{lr}
\multicolumn{2}{c}{ Rural (nonmetropolitan) } \\
Males & 23 \\
Females & 20 \\
Urban (metropolitan) \\
Males & 24 \\
Females & 20
\end{tabular}

51

47

22

4

20

28

5

Source: U.S. Census Bureau Current Population Survey.

Adult cohabitors in rural areas also have less favorable employment experiences relative to their urban counterparts. Unemployment rates among cohabiting men are 3 percentage points higher in rural areas than in urban areas (11 percent versus 8 percent) (see Table 4 ). Rural and urban cohabiting women are equally likely to be unemployed (6 percent) but one-third (33 percent) of cohabiting women in rural areas are not working or actively looking for work, 
TABLE 4. LABOR FORCE STATUS OF MALE AND FEMALE COHABITORS IN COHABITING HOUSEHOLDS WITH CHILDREN BY METROPOLITAN STATUS: 2005-2006

$\begin{array}{lccc}\begin{array}{c}\text { Percent } \\ \text { working }\end{array} & \begin{array}{c}\text { Percent } \\ \text { unemployed }\end{array} & \begin{array}{c}\text { Percent not } \\ \text { in labor force }\end{array} \\ \begin{array}{lccc}\multicolumn{2}{l}{\text { Rural (nonmetropolitan) }} \\ \text { Males }\end{array} & 79 & 11 & 9 \\ \text { Females } & 61 & 6 & 33 \\ \text { Urban (metropolitan) } & & 8 & 10 \\ \text { Males } & 82 & 6 & 29 \\ \text { Females } & 66 & & \end{array}$

Note: "Working" includes "working" and "with job, not at work." "Unemployed" includes "unemployed, looking" and "unemployed, layoff."

Source: U.S. Census Bureau Current Population Survey.

compared with 29 percent in urban areas. It is possible that women who are not in the labor force are more likely to see cohabitation as a way to survive economically.

The unemployment rates may understate the true employment differences between rural and urban workers in cohabiting households, because rural workers are much more likely to be discouraged workers-those who were once in the labor force but who after a long unemployment spell have given up looking for a new job-or otherwise underemployed. ${ }^{6}$ Official unemployment rates do not count these individuals.

\section{Increasing Economic Stress Is Likely One Reason for the Rise in Cohabitation in Rural Areas}

We believe that the more rapid increase of cohabiting in rural households may be tied to growing economic stress in rural America. The largest increase in the percentage of rural children living in cohabiting households occurred after 2000 (see Table 1), a particularly difficult time economically for low-income rural families. One indicator of this growing strain in rural areas is the sharp rise in child poverty, from 19 percent in 2000 to 22 percent in $2006 .^{7}$ In addition, rural cohabitation rates first started to outstrip those in urban areas around 2000, a time when many low-wage workers in rural America began to struggle. ${ }^{8}$ Other research has shown a connection between economic conditions and changing family structure. ${ }^{9}$

Moreover, welfare rolls have fallen since 2000, and welfare payments are typically lower in states with large rural populations. ${ }^{10}$ Consequently, for single, rural women with children, joining a household with a man may be an economic survival strategy.
The difference in behavior between adults with and without children lends further weight to the "survival strategy" theory. Female-headed households without children (who we assume feel less economic pressure) have similar cohabitation rates in rural and urban areas, but rates of cohabitation are higher among female-headed households with children in rural areas than in urban areas. ${ }^{11}$ For those facing the highest economic stress-rural unmarried women with children - the cohabitation rates are the highest.

\section{Policy Implications}

\section{Federal Marriage Initiative}

From welfare reform in 1996 to President George W. Bush's Marriage Initiative of 2005, the federal government has been trying to encourage formation and maintenance of marriedcouple families. Cohabiting parents may be good targets for the Marriage Initiative because they already share a residence and are "closer" to marriage than unmarried parents who live apart. Given the higher rate of cohabitation in rural America, the government might want to focus more of its efforts there. Moreover, cohabiting women in rural areas are more likely to marry their cohabiting partners than their urban counterparts are, ${ }^{12}$ suggesting cohabitation may be more often perceived as a stepping stone to marriage in rural than urban areas.

\section{Cohabiting and Public Assistance}

Needs-based public assistance programs are inconsistent in how they treat cohabiting couples. ${ }^{13}$ For example, states vary on how they count income from a cohabiting partner, and eligibility is further complicated by the cohabiting male's paternity status. In many states, low-income, cohabiting, biological parents may be able to obtain certain types of public assistance that a married couple would not. ${ }^{14}$ Not only do states differ in their laws, but officials in rural areas sometimes more strictly interpret eligibility rules governing cohabiting couples, which may reflect stronger cultural pressures to marry. ${ }^{15}$

Inconsistency in how cohabiting couples are treated in public programs is likely to have a bigger impact on rural families, because nearly one-half (46 percent) of cohabiting rural households with children receive some type of meanstested public assistance, in contrast to about one-third ( 35 percent) of urban cohabiting households with children. The rural-urban difference results, in part, from more families in rural America being poor. The types of assistance examined here include free or reduced-price school lunch (the most common form of assistance for rural families), public housing, food stamps, Supplemental Security Income, and Temporary Assistance for Needy Families. 
The lack of consistent interpretation and enforcement of eligibility rules is thus likely to result in some rural families losing out on necessary services. Therefore, more attention is warranted to how program eligibility policies affect cohabiting-parent families, particularly in rural areas with their higher poverty rates.

\section{Cohabiting and the M easurement of Poverty}

The official measure of poverty does not include the income of a cohabiting partner in its calculation of family income. As a result, the number of children in poverty is likely to be overestimated. Although cohabiting partners do not share income the same way married couples do, it seems more reasonable to include income from a cohabiting partner in the poverty estimate than to ignore it. ${ }^{16}$ When income from a cohabiting partner is included, cohabiting families fare better economically than single-mother families in both rural and urban areas. However, even with two incomes counted, cohabiting families with children in rural areas are poorer than in urban areas. ${ }^{17}$

When the government implemented its poverty measure in the mid-1960s, the number of cohabiting couples was quite small (probably less than 1 million), and cohabitation had little impact on poverty estimates for most groups. However, as the number of cohabitors has grown, so has the potential impact of mismeasurement. Because cohabitingparent families are a larger share of families in rural America, this mismeasurement will likely have a larger impact on poverty figures for rural children. A more realistic treatment of income from cohabiting partners would give us a more accurate understanding of childhood poverty, particularly in rural America.

Several researchers and policy makers are calling for a reformulation of the official poverty definition that was adopted in the 1960s. ${ }^{18}$ Given the growing share of children in cohabiting-couple families, any effort to devise a new definition of poverty should address how the incomes of adults in cohabiting relationships are treated.

\section{Key Findings}

- The number of children living with cohabiting parents has increased more rapidly than any other family form during the past decade.

- The percentage of children living in cohabiting families is higher in rural than in urban areas. In 2005-2006, 7 percent of children in rural America were living in cohabiting households compared with 4 percent in urban America.

- The biggest increase in the share of rural children living in cohabiting-couple households has occurred since 2000, as economic conditions in rural America worsened.

- The poverty rate for rural children in cohabiting households is 21 percent compared to only 15 percent in cohabiting urban households.

- Like most rural adults, relative to their urban counterparts, rural adults in cohabiting households with children have lower levels of education, employment, and income.

- Rural cohabiting-parent families are more vulnerable economically than their urban counterparts. For example, 60 percent of rural children in cohabiting households live in low-income households (income below 200 percent of the poverty line) while only 47 percent of urban children in cohabiting households do so.

- Rural economic vulnerability may be driving the higher levels of cohabitation there. 


\section{Data and Methodology}

The data for this study come from the Census Bureau's March Annual Social and Economic Supplement (ASEC) from the Current Population Survey (CPS), a monthly survey conducted for the Bureau of Labor Statistics. The Census Bureau did not begin to regularly identify cohabiting families in the CPS until 1995, when it included "unmarried partner" as an answer option to the question on the relationship to the reference person.

We combine adjacent years of the CPS survey from 1995-1996 to 2005-2006 to provide larger sample sizes at each point in time. This produces more precise and reliable estimates. The way the CPS sample is constructed, households are in the March sample for two consecutive years. To ensure that households are not counted twice, we include all households in the first year of the two-year time period, and in the second year, we include only households that were not in the sample the previous year.

A household is designated as cohabiting if an oppositesex unmarried partner of the reference person is identified. Married households are those in which an opposite-sex spouse of the reference person is identified. A household is categorized as single-mother or single-father if the reference person does not have a spouse or cohabiting partner and she or he has children younger than 18 living in the household. Children are categorized on the basis of household designation and their relationship to the reference person or the reference person's spouse or partner. Analyses are based on children under age 18 living in the household who were not designated as the reference person, the reference person's spouse, or the reference person's unmarried partner.

We determine poverty status at the household level. Households include everyone living in the housing unit, while families are determined by relationships among people in the housing unit. Cohabiting couples would not be families under the Census Bureau's definition. We use the Department of Health and Human Services' (DHHS) poverty guidelines for each year, which take into account the number of persons in the household in determining the correct poverty threshold. We use these poverty guidelines rather than the Census Bureau's poverty thresholds, because the Census Bureau's thresholds are calculated at the family level, while the DHHS guidelines can be calculated for families or households. (However, comparable estimates using the Census Bureau's thresholds yielded similar results.) The poverty guideline for each household is divided by the total household income. If the result is less than one, the household is categorized as being in poverty. We then conducted poverty analyses at the child level. These analyses are conducted using weights designed for the ASEC at the person level.

\section{Endnotes}

1. We want to emphasize that this report only looks at cohabiting couples with children in the household, which are less than one-half of all cohabiting couples.

2. Data available from the Census Bureau's 2007 ACS file Table B09008, available online at http://factfinder.census. gov/servlet/DTTable?_bm=y\&-ds_name=ACS_2007_1YR_ G00_\&-gc_url=010:00|01|43|\&-CONTEXT=dt\&-mt_ name=ACS_2007_1YR_G2000_B09008\&-redoLog=false\&geo_id=01000US\&-_showChild $=Y \&$-format $=\&$-_lang=en\&SubjectID $=15234282$. Note that cohabitation is measured differently in the ACS than in the CPS data used for this paper.

3. It should be noted that counties that were classified as nonmetro, or rural, changed during the 1995 to 2006 period, with the biggest change occurring in 2003. In that year, the Office of Management and Budget made slight changes to the definition of metropolitan areas, resulting in some counties shifting status. Those changes were incorporated into the CPS in 2004, 2005, and 2006. However, other analysis suggests that it is unlikely that the changing designation of counties had much impact on the trends shown here.

4. Anastasia R. Snyder and Diane K. McLaughlin, "Economic Well-being and Cohabitation: Another Nonmetro Disadvantage?" Journal of Family and Economic Issues 27 (2006): 562-582; Anastasia R. Snyder, Diane K. McLaughlin, and Jill Findeis, "Household Composition and Poverty among Female-Headed Households with Children: Differences by Race and Residence," Rural Sociology 71 (2006): 597-624.

5. Wendy D. Manning and Daniel T. Lichter, "Parental Cohabitation and Children's Economic Well-Being," Journal of Marriage and the Family 58 (1996): 998-1010; Wendy D. Manning and Susan L. Brown, "Children's Economic WellBeing in Married and Cohabiting Parent Families," Journal of Marriage and Family 68 (2006): 345-362; Snyder and McLaughlin, "Household Composition and Poverty among Female-Headed Households with Children."

6. Tim Slack and Leif Jensen, "Race, Ethnicity, and Underemployment in Nonmetropolitan America: A 30-Year Profile," Rural Sociology 67 (2002): 208-233.

7. William P. O'Hare and Sarah Savage, "Child Poverty High in Rural America," Fact Sheet No. 6 (Durham, NH: Carsey Institute, University of New Hampshire, 2007). Available online at http://carseyinstitute.unh.edu/publications/FS_RuralChildPoverty_07.pdf. 
8. Amy Glasmeier and Priscilla Salant, "Low-Skill Workers in Rural America Face Permanent Job Loss," Policy Brief No. 2 (Durham, NH: Carsey Institute, University of New Hampshire, 2006). Available online at http://carseyinstitute.unh. edu/publications/PB_displacedworkers_06.pdf.

9. William P. O'Hare, Recent Changes in the Percent of Children Living in Single-Mother Families, KIDS COUNT Working Paper (Washington, DC: Annie E. Casey Foundation, July 2003).Available online at http://www.aecf.org/ upload/PublicationFiles/DA3622H1270.pdf.

10. Leif Jensen and David J. Eggebeen, "Nonmetropolitan Poor Children and Reliance on Public Assistance," Rural Sociology 59 (1994): 45-65; William P. O'Hare Child Poverty in Rural America, Reports on America (Washington, DC: Population Reference Bureau, 2004), 16.

11. Anastasia R. Snyder and Diane K. McLaughlin, "Economic Well-being and Cohabitation: Another Nonmetro Disadvantage?" Journal of Family and Economic Issues 27 (2006): 562-582.

12. Susan L. Brown and Anastasia R. Snyder, "Residential Differences in Cohabitors' Union Transitions," Rural Sociology 71 (2006): 311-344.

13. Robert A. Moffitt, Robert Reville, and Anne E. Winkler, "Beyond Single Mothers: Cohabitation and Marriage in the AFDC Program,” Demography 35 (1998): 259-278.

14. Ibid.

15. Brian J. Brown and Daniel T. Lichter, "Poverty, Welfare, and the Livelihood Strategies of Rural Single Mothers," Rural Sociology 69 (2004): 282-301.

16. Wendy D. Manning and Susan L. Brown, "Children's Economic Well-Being in Married and Cohabiting Parent Families," Journal of Marriage and Family 68 (2006): 345362; Catherine Kenney, "Cohabiting Couple, Filing Jointly? Resource Pooling and U.S. Poverty Policies," Family Relations 53 (2004): 237-247.

17. Brian J. Brown and Daniel T. Lichter, "Poverty, Welfare, and the Livelihood Strategies of Rural Single Mothers," Rural Sociology 69 (2004): 282-301; Snyder and McLaughlin, "Economic Well-being and Cohabitation: Another Nonmetro Disadvantage?"; Snyder, McLaughlin, and Findeis, "Household Composition and Poverty among Female-Headed Households with Children".
18. Douglass Nelson, "Counting What Counts," Washington Times, August 29, 2007; National Academy of Sciences, Measuring Poverty: A New Approach (Washington, DC: National Academy Press, 1995). Available online at http://www.nap. edu/readingroom/books/poverty/.

\section{ABOUT THE AUTHORS}

William O'Hare is a visiting senior fellow at the Carsey Institute. (bbohare@comcast.net)

Wendy Manning is director of the Center for Family and Demographic Research and professor of sociology at Bowling Green State University. (wmanning@bgsu.edu)

Meredith Porter is a research affiliate of the Center for Family and Demographic Research and an instructor of sociology at Bowling Green State University. (mjanep@bgsu.edu)

Heidi Lyons is a doctoral candidate in sociology at Bowling Green State University. (hlyons@bgsu.edu)

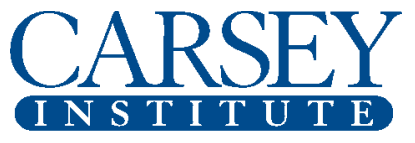

Building knowledge for families and communities

The Carsey Institute conducts policy research on vulnerable children, youth, and families and on sustainable community development. We give policy makers and practitioners timely, independent resources to effect change in their communities.

The Carsey Institute is supported by the Annie E. Casey Foundation's initiative to strengthen rural families and by the W.K. Kellogg Foundation.

Huddleston Hall

73 Main Street

Durham, NH 03824

(603) 862-2821

www.carseyinstitute.unh.edu 